\title{
DUKUNGAN SOSIAL, INTERAKSI KELUARGA, DAN KUALITAS PERKAWINAN PADA KELUARGA SUAMI ISTRI BEKERJA
}

\author{
Tin Herawati $^{\star}$, Berti Kumalasari, Musthofa, Fatma Putri Sekaring Tyas \\ Departemen IImu Keluarga dan Konsumen, Fakultas Ekologi Manusia, Institut Pertanian Bogor, \\ Bogor 16680, Indonesia
}

*)Email: gmsk_29@yahoo.com

\begin{abstract}
Abstrak
Fenomena keluarga suami-istri bekerja dapat menyebabkan perubahan dukungan sosial dan interaksi keluarga sehingga memengaruhi kualitas perkawinan. Tujuan dari penelitian adalah menganalisis pengaruh dukungan sosial dan interaksi keluarga terhadap kualitas perkawinan pada keluarga dengan suami istri bekerja. Responden pada penelitian ini adalah istri yang bekerja sebagai PNS (Pegawai Negeri Sipil) di Pemerintah Kota Bogor dan memiliki anak usia sekolah (6-12 tahun) serta bersedia untuk dijadikan responden, dengan jumlah 60 istri bekerja. Responden dipilih secara purposive. Hasil penelitian menunjukkan bahwa lebih dari setengah istri menerima dukungan sosial tinggi dari keluarga luas dan tetangga. Istri mendapatkan dukungan emosional yang optimal dari keluarga luas. Interaksi keluarga yang mencakup interaksi suami-istri dan ibu-anak menunjukkan bahwa hampir seluruh keluarga mempunyai interaksi yang cukup baik. Proporsi terbesar yaitu dua pertiga istri merasa interaksi ibu-anak berada pada kategori tinggi sedangkan proporsi terbesar istri menilai interaksi suami-istri berada pada kategori sedang. Sementara itu, kualitas perkawinan yang dilihat dari dimensi kebahagiaan dan kepuasan menunjukkan bahwa proporsi terbesar istri merasa kualitas perkawinan tinggi. Penelitian ini menemukan bahwa faktor yang paling berpengaruh positif signifikan terhadap kualitas perkawinan pada keluarga dengan suami istri bekerja adalah interaksi keluarga.
\end{abstract}

Kata kunci: dukungan sosial, interaksi keluarga, kualitas perkawinan, keluarga suami istri bekerja

\section{Social Support, Family Interaction, and Marital Quality of Dual Earner Family}

\begin{abstract}
The phenomenon of dual-earner family can lead to changes in social support and family interaction that affect the quality of marriage. This study aims to analyze the influence of social support and family interaction on the quality of marriage in families with husband and wife work. Respondent in this research is the wife who works as the civil servant (PNS) in Bogor City Government and have school age child (6-12 year) and willing to be respondent, with an amount of 60 working wives. Respondents were chosen purposively. The results show that more than half of wives receive high social support from extended families and neighbors. Wives get optimal emotional support from extended family. Family interactions that include husband-wife and mother-child interactions show that almost all families have good interactions. The highest proportion is that two-thirds of wives feel that mother-child interaction is in the high category whereas the most substantial portion of wives assessing husband-wife interaction is in the moderate category. Meanwhile, the quality of marriage seen from the dimensions of happiness and satisfaction shows that the highest proportion of wives feels the quality of marriage is high. This study found that the factors that have the most positive significant effect on marital quality in a family with husband and wife work are family interaction.
\end{abstract}

Keyword: dual earner family, family interaction, marital quality, social support

\section{PENDAHULUAN}

Kehidupan modern saat ini, telah terjadi pergeseran nilai-nilai dalam pola kehidupan di masyarakat yaitu keluarga tradisional menjadi keluarga modern. Keluarga modern memberikan kesempatan bagi istri untuk bekerja di sektor publik (Puspitawati, 2012). Berdasarkan data dari Survei Angkatan Kerja
Nasional (SAKERNAS) pada tahun 2015-2016, Tingkat Partisipasi Angkatan Kerja (TPAK) perempuan mengalami peningkatan dari bulan Agustus 2015 sebesar 31,54 persen menjadi 33,25 persen pada bulan Agustus 2016. Ketika istri bekerja maka pembagian tugas di keluarga juga akan terpengaruh, dikarenakan ada perubahan alokasi waktu istri yang harus berbagi antara rumah dan tempat bekerja. 
Pilihan ibu bekerja di luar rumah, ketiadaan penyesuaian diri dan saling pengertian antaranggota keluarga tentu saja akan menyebabkan kebahagiaan perkawinan sulit diperoleh. Bahkan konflik akan terus berkembang jika permasalahan dibiarkan berlarut-larut dan dimungkinkan akan mengalami perpisahan bahkan perceraian (Susmayanti et al., 1995). Hasil penelitian dari Sunarti, Rizkillah, dan Muktiyah (2014) menemukan bahwa istri bekerja akan berdampak mengalami konflik yang mengganggu keluarga daripada konflik keluarga mengganggu kerja. Hal ini dapat terjadi apabila istri lebih banyak menggunakan waktunya untuk bekerja dibandingkan dengan menghabiskan waktu bersama keluarga. Puspitawati (2009) menyatakan bahwa kondisi istri bekerja yang lebih mementingkan pekerjaan daripada keluarga, akan cenderung kurang optimal melakukan manajemen stres serta kesehatan mental yang kurang, sehingga menghabiskan waktu lebih banyak untuk melakukan kegiatan personal, seperti tidur, guna untuk melepaskan segala beban yang ditanggung istri, terutama beban pekerjaan. Konflik kerja keluarga memengaruhi beberapa aspek, yaitu psychological well-being, depresi, kepuasan perkawinan, dan kepuasan hidup (Greenhaus \& Beutell, 1985).

Ketidakpuasan yang dirasakan dapat memberikan dampak negatif pada perkawinan, salah satu dampaknya perkawinan yang berujung pada perceraian (Larasati, 2012; Kusumowardhani, 2012). Pada tahun 2013 terdapat 5.165 kasus perceraian (Kemenag, 2013) dan meningkat pada tahun 2014 menjadi 7.378 kasus di Kota Bogor (Kemenag, 2014). Direktorat Jenderal Badan Peradilan Agama MA RI, juga menyatakan bahwa kasus perceraian meningkat pada tahun 2013 sebesar 324.247 kasus menjadi 344.237 kasus pada tahun 2014. Penyebab terbesar pemicu perceraian adalah tidak ada keharmonisan, ekonomi, perselisihan dan gangguan pihak ketiga. Kasus perceraian yang semakin meningkat mengindikasikan pasangan suami istri tidak dapat melakukan pembagian peran, pekerjaan dan waktu dengan baik sehingga interaksi keluarga tidak dapat berjalan dengan baik serta menyebabkan kualitas perkawinan kurang optimal. Menurut Kerkmann et al. (2000) perceraian mengindikasikan kurangnya kepuasan perkawinan.

Kualitas perkawinan bagian yang dapat memberi kebahagiaan dan kesejahteraan bagi pasangan suami dan istri sehingga dapat menjaga keharmonisan perkawinan. Kualitas perkawinan merupakan cermin keharmonisan pasangan suami dan istri serta menjadi salah satu faktor mencegah terjadinya perceraian (Puspitawati, 2012). Kualitas perkawinan tercermin dari kondisi fisik dan psikologis anggota keluarga, meliputi aspek kebahagiaan dan kepuasan perkawinan dalam hal ekonomi, hubungan intim, komunikasi, pengasuhan anak, komitmen perkawinan dan pengasuhan anak (Bulanda, Brown, \& Yamashita, 2016; Litcher \& Carmalt, 2008). Kualitas perkawinan berhubungan kuat dengan evaluasi kehidupan seseorang secara keseluruhan. Carr et al., (2014) menyebutkan adanya lima dimensi yang merefleksikan komponen kualitas perkawinan, yaitu ketidakstabilan perkawinan, interaksi perkawinan, jumlah dan kehebatan ketidaksetujuan, dan persepsi masalah dalam perkawinan. Rendahnya kualitas perkawinan akan menghasilkan perasaan ketidakstabilan dalam perkawinan (Lewis \& Spanier, 1979). Kepuasan perkawinan merupakan salah satu dari dimensi kualitas perkawinan yang diukur berdasarkan persepsi istri dalam menilai kehidupan perkawinannya yang relatif dinamis dari tiga aspek yaitu: aspek ekonomi, pengasuhan anak, cinta dan hubungan intim (Rizkillah, 2014). Hubungan positif antara dukungan sosial dan interaksi keluarga menunjukkan tingkat kepuasan perkawinan yang tinggi dalam keluarga (Pratiwi, 2016).

Bagi keluarga dengan suami dan istri bekerja, dukungan sosial merupakan salah satu sistem pendukung yang diperlukan untuk menjaga keberfungsian keluarga. Dukungan sosial adalah kebutuhan mendasar bagi individu untuk melanjutkan hubungan sosial, mengatasi kesepian, beradaptasi dengan masyarakat, dan mempertahankan keadaan psikologis yang stabil (Gunuc \& Dogan, 2013). Hasil penelitian dari Sunarti et al. (2005) memperlihatkan bahwa dukungan sosial bagi keluarga berupa bantuan fisik dan nonfisik dari keluarga luas, tetangga, atau teman yang mendatangkan nilai positif kepada keluarga sehingga mengoptimalkan fungsi dan perannya. Dukungan sosial dapat diperoleh melalui keluarga, masyarakat, maupun dari lembaga-lembaga masyarakat yang berada di lingkungan sekitar untuk mendukung, maupun anggota keluarga atau teman yang dapat menolong mengurangi stres yang dialami individu di dalam keluarga (Puspitawati, 2012). Jika pasangan memiliki dukungan sosial yang cukup, tidak hanya mengurangi depresi, tetapi akan meningkatkan kepuasan perkawinan. Sebuah penelitian menemukan bahwa tingginya dukungan sosial akan meningkatkan kepuasan perkawinan sehingga gejala depresi 
dapat turun dan mampu mengatasi stres (Khan \& Aftab, 2013). Pasangan suami istri yang bekerja akan membutuhkan dukungan sosial untuk mengatasi dan menjalankan tugas perkembangan keluarganya. Dukungan sosial bagi pasangan suami istri bekerja juga dapat mengurangi resiko pertengkaran dan stres. Permasalahan dalam perkawinan dapat ditanggulangi antara lain dengan meningkatkan dukungan sosial (Puspitawati, 2012). Dukungan sosial dapat memengaruhi interaksi individu di dalam keluarga yaitu dukungan emosional terhadap pasangan (Selvarajan et al., 2013).

Selain dukungan sosial, kepuasan perkawinan pada keluarga dengan suami istri bekerja juga dapat ditentukan dengan interaksi yang terjalin antaranggota keluarga dengan keterbatasan waktu yang dimiliki keluarga. Interaksi keluarga adalah hubungan yang terjalin antaranggota keluarga yang mencakup interaksi suami-istri, interaksi ibu-anak, dan juga interaksi ayahanak yang melibatkan komunikasi dan emotional bonding untuk mencapai pemahaman yang lebih baik dalam melaksanakan peran dan fungsi keluarga (Puspitawati \& Setioningsih, 2011; Waldinger \& Schulz, 2006).

Interaksi pasangan suami istri mempunyai manfaat untuk menjaga keselarasan fungsi keluarga, terutama dalam hal pembagian peran, tugas, dan pekerjaan (Puspitawati, 2012). Keluarga dengan suami istri bekerja tentu saja akan memberikan keterbatasan waktu yang dimiliki antara ibu dan anak dan akan berpengaruh pada perkembangan anak (Puspitawati \& Setioningsih, 2011). Wheatley (2014) menyatakan bahwa rendahnya interaksi keluarga atau menipisnya perasaan lekat dapat membuat suasana keluarga menjadi tidak harmonis. Kebahagiaan perkawinan tercapai dengan adanya komunikasi dan keterbukaan antara pasangan dan keluarga pasangan sehingga dapat menjaga komitmen perkawinan (Rizkillah, 2014; Tyas \& Herawati, 2017). Komunikasi dan saling terbuka merupakan salah satu hal yang penting dalam mengoptimalkan dukungan sosial, interaksi keluarga dan kualitas perkawinan. Berdasarkan hal tersebut, peneliti ingin mengetahui lebih lanjut mengenai pengaruh dukungan sosial dan interaksi keluarga terhadap kualitas perkawinan pada keluarga suami istri bekerja. Oleh karena itu, penelitian ini bertujuan untuk mengidentifikasi dukungan sosial, interaksi keluarga, dan kualitas perkawinan pada keluarga dengan suami istri bekerja dan menganalisis pengaruh dukungan sosial, interaksi keluarga terhadap kualitas perkawinan pada keluarga dengan suami istri bekerja.

\section{METODE}

Desain cross sectional study dengan teknik pengumpulan data melalui self-report menggunakan alat bantu kuesioner terstruktur yang digunakan di penelitian ini. Lokasi penelitian dipilih secara purposive, yaitu instansi-instansi di lingkungan Pemerintah Kota Bogor, Jawa Barat. Populasi penelitian ini adalah seluruh keluarga suami-istri bekerja di kantor Pemerintah Kota Bogor. Responden pada penelitian ini adalah istri yang bekerja sebagai PNS (Pegawai Negeri Sipil) di lingkungan Pemerintah Kota Bogor dan memiliki anak usia sekolah (6-15 tahun) serta bersedia untuk dijadikan responden. Jumlah responden pada penelitian ini yaitu 60 istri bekerja yang dipilih secara purposive di lokasi tersebut. Data penelitian yang dikumpulkan berupa data primer dan data sekunder.

Cara mengumpulkan data primer melalui selfreport oleh istri yang bekerja menggunakan alat bantu kuesioner. Data primer yang dikumpulkan meliputi: (1) karakteristik keluarga contoh (usia, lama menikah, lama pendidikan, pekerjaan, pendapatan keluarga dan jumlah anggota keluarga), (2) dukungan sosial (dukungan keluarga besar dan tetangga) yang dikumpulkan dari instrumen yang dimodifikasi dari Sunarti et al. (2005), Sarafino (1996) dan Cubbin (1987) dengan nilai Cronbach's alpha 0,721 , (3) interaksi keluarga yang dikumpulkan dengan instrumen yang dikembangkan oleh Chuang (2005), (4) kualitas perkawinan yang mencakup dimensi kebahagiaan dan dimensi kepuasaan dengan menggunakan kuesioner dari konsep Conger et al. (1990) yang dikembangkan oleh Sunarti et al. (2005).

Kuesioner dukungan sosial berjumlah 26 pertanyaan dengan pilihan jawaban " $0=$ tidak, 1=iya". Sementara itu, kuesioner interaksi keluarga berjumlah 59 pertanyaan yang terdiri dari interaksi ibu-anak dengan 30 pertanyaan dengan nilai Cronbach's alpha 0,979 dan interaksi suami-istri dengan 29 pertanyaan dengan nilai Cronbach's alpha 0,965 dengan pilihan jawaban "1=tidak pernah, 2=kadangkadang, $3=$ sering, $4=$ selalu Kuesioner kualitas perkawinan mempunyai nilai Cronbach's alpha 0,942 dan mempunyai 40 pertanyaan dengan pilihan jawaban " $0=$ tidak, $1=$ iya".

Informasi yang dikumpulkan selanjutnya diolah melalui proses editing, coding, input data, 
cleaning, dan analisis data. Analisis data menggunakan program Microsoft Office Excel dan Statistical Package for Social Science (SPSS). Data diolah dengan menggunakan indeks $(0,0-100,0)$. Cut off yang digunakan adalah rendah $(0,0-60,0)$, sedang $(60,0-80,0)$, dan tinggi $(80,0-100,0)$. Data dianalisis secara deskriptif (rata-rata, standar deviasi, nilai minimum dan nilai maksimum) dan inferensia (regresi linier berganda).

\section{HASIL}

\section{Karakteristik keluarga}

Hasil penelitian menunjukkan bahwa rata-rata usia istri adalah 40,45 tahun dan rata-rata usia suami adalah 43,28 tahun, yang menunjukkan bahwa sebagian besar berada di kategori usia dewasa madya. Rata-rata besar keluarga adalah 4 orang dan termasuk dalam kategori keluarga kecil. Rata-rata lama pendidikan istri adalah 16 tahun dan rata-rata pendidikan suami adalah 15 tahun yang menunjukkan bahwa rata-rata lama pendidikan istri lebih tinggi dibandingkan suami. Hasil penelitian juga menunjukkan bahwa lama menikah pasangan berkisar antara 7 sampai 20 tahun. Rata-rata pendapatan per kapita keluarga per bulan sebesar Rp2.569.643,00. Pekerjaan suami dalam penelitian ini cukup beragam dengan persentase tertinggi adalah PNS $(43,3 \%)$. Jenis pekerjaan lainnya yang dimiliki oleh suami adalah wiraswasta $(6,7 \%)$, swasta (40,0\%), POLRI/TNI (6,7\%), dan BUMN/BUMD (3,3\%).

\section{Dukungan Sosial}

Dukungan sosial yang diukur pada penelitian ini adalah dukungan keluarga luas dan dukungan tetangga. Hasil penelitian pada Tabel 1 menunjukkan bahwa sekitar satu dari dua $(53,3 \%)$ istri menerima dukungan sosial tinggi dari keluarga luas dan tetangga. Para istri pada penelitian ini merasa mendapatkan dukungan emosional yang optimal dari keluarga luas. Hal ini tercermin dari pernyataan bahwa istri mendapat dukungan dari keluarga luas dalam bentuk mendengarkan masalah yang dihadapi $(93,3 \%)$, memperlihatkan perasan cinta dan kepedulian (96,7\%), hubungan yang akrab
(95,0\%), menghargai perasaan (100,0\%), merasa sebagai bagian penting dalam keluarga $(100,0 \%)$ dan memahami perasaan $(78,3 \%)$.

Dalam aspek dukungan instrumental dari keluarga luas, sekitar enam dari sepuluh istri menyatakan tidak menerima bantuan keuangan $(60,0 \%)$ dan bantuan barang $(58,3 \%)$. Hanya saja, istri mendapat dukungan sosial dari keluarga luas dalam bentuk bantuan pengasuhan anak $(61,7 \%)$ dan solusi ketika menghadapi masalah (88,3\%). Sementara itu, dukungan informasi yang diterima oleh istri yang paling besar ditemukan proporsi istri adalah dukungan untuk berbagi kesulitan $(70,0 \%)$ dan istri juga mendapatkan informasi terkait dengan keluarga inti $(86,7 \%)$.

Hasil penelitian ini juga menemukan bahwa istri menerima dukungan sosial dari tetangga meliputi dukungan emosional, instrumental, dan informasi yang tercapai dengan baik. Dukungan tetangga pada kondisi emosional mempunyai proporsi terbesar khususnya pada pernyataan bahwa istri merasa dicintai dan merasa aman pada lingkungan $(91,7 \%)$, tetangga menghargai perasaan istri $(90,0 \%)$, dan istri merasa menjadi bagian penting dalam masyarakat (86,7\%). Namun, dukungan tetangga berupa dukungan instrumental dan dukungan informasi pada beberapa istri masih dirasakan rendah seperti pada pernyataan berbagi dan bertukar pikiran dengan tetangga terkait masalah yang dihadapi $(38,3 \%)$ dan bertukar informasi tentang berbagai hal dengan tetangga $(48,3 \%)$.

\section{Interaksi Keluarga}

Berdasarkan hasil penelitian pada Tabel 2 dapat diketahui bahwa sekitar satu dari dua istri $(53,3 \%)$ merasa interaksi keluarganya berada pada kategori tinggi. Hal ini dapat dilihat dari interaksi suami-istri dan interaksi ibu-anak dalam keluarga yang telah baik seperti istri menunjukkan rasa kasih sayang kepada suami dan anaknya. Akan tetapi masih beberapa harus dioptimal istri seperti menyediakan waktu sarapan bersama dan lebih memerhatikan anak dalam hal mengingatkan jika ada tugas dari sekolah.

Tabel 1 Sebaran istri berdasarkan kategori dimensi dukungan sosial

\begin{tabular}{|c|c|c|c|c|c|c|c|c|}
\hline \multirow{3}{*}{ Sumber Dukungan Sosial } & \multicolumn{6}{|c|}{ Kategori } & \multirow{3}{*}{$\begin{array}{l}\text { Minimal- } \\
\text { Maksimal }\end{array}$} & \multirow{3}{*}{$\begin{array}{c}\text { Rata-rata } \pm \\
\text { SD }\end{array}$} \\
\hline & \multicolumn{2}{|c|}{$\begin{array}{c}\text { Rendah } \\
(00,0-60,0)\end{array}$} & \multicolumn{2}{|c|}{$\begin{array}{c}\text { Sedang } \\
(60,0-79,0)\end{array}$} & \multicolumn{2}{|c|}{$\begin{array}{c}\text { Tinggi } \\
(80,0-100,0)\end{array}$} & & \\
\hline & $n$ & $\%$ & $\mathrm{n}$ & $\%$ & $\mathrm{n}$ & $\%$ & & \\
\hline Keluarga luas & 2 & 3,3 & 24 & 40,0 & 34 & 56,7 & $31-100$ & $82,00 \pm 14,29$ \\
\hline Tetangga & 7 & 11,7 & 27 & 45,0 & 26 & 43,3 & $31-100$ & $77,00 \pm 17,25$ \\
\hline Dukungan sosial total & 6 & 10,0 & 22 & 36,7 & 32 & 53,3 & $46-100$ & $79,00 \pm 12,90$ \\
\hline
\end{tabular}


Interaksi Suami-Istri. Hasil penelitian pada Tabel 2 menunjukkan bahwa proporsi terbesar istri adalah menilai interaksi suami-istri pada kategori sedang $(46,7 \%)$. Hal ini dapat dilihat dari beberapa pernyataan dengan proporsi yang kecil pada pernyataan negatif bahwa istri tidak pernah menghindari perbuatan yang dapat membuat suami sedih $(6,7 \%)$, istri tidak menjelaskan sesuatu yang tidak dipahami oleh suami $(6,7 \%)$, istri tidak menyediakan waktu untuk sarapan pagi bersama suami $(6,7 \%)$, istri tidak menyediakan waktu untuk makan malam bersama suami $(8,3 \%)$, istri tidak menemani suami menonton TV $(6,7 \%)$ dan istri tidak menghubungi suami saat sedang bekerja (6,7\%). Meskipun begitu, masih ditemukan sebanyak 15 persen istri yang merasa bahwa interaksi suami-istri tergolong rendah. Hasil yang tersaji pada Tabel 2 menunjukkan bahwa sebanyak 38,3 persen istri merasa bahwa interaksinya dengan suami sudah berada pada kategori tinggi. Hasil tersebut dapat dilihat dari proporsi yang cukup banyak khususnya pada beberapa pernyataan seperti istri yang selalu menunjukkan rasa kasih sayang kepada suami (68,3\%), menyediakan waktu untuk berinteraksi dengan suami $(56,7 \%)$, mendengarkan cerita suami $(55,0 \%)$, membicarakan hal-hal yang tidak sepaham dengan suami secara baik-baik $(51,7 \%)$. Hasil yang menemukan bahwa hanya sekitar empat dari sepuluh istri yang merasa interaksi suami-istri berada pada kategori tinggi mengindikasikan masih perlunya ditingkatkan kualitas interkasi suami-istri pada penelitian ini yang mana keduanya berstatus bekerja. Kondisi tersebut juga mengindikasikan bahwa suami-istri sama-sama sibuk dengan pekerjaan masing-masing, sehingga suami atau istri mengalami kesulitan dalam berinteraksi dengan keluarga.

Interaksi Ibu-Anak. Berdasarkan hasil penelitian pada Tabel 2 terlihat bahwa dua pertiga $(66,7 \%)$ istri merasa interaksi ibu-anak berada pada kategori tinggi. Hal ini dapat dilihat dari proporsi yang rendah khususnya pada beberapa pernyataan seperti ibu yang tidak pernah memberikan saran kepada anak terkait masalahnya (6,7\%), ibu tidak mengingatkan anak untuk melakukan tugasnya $(6,7 \%)$, ibu tidak mengalah ketika berdebat dengan anak (13,3\%), dan ibu tidak menyediakan waktu untuk sarapan pagi bersama anak $(6,7 \%)$. Selain itu, juga terlihat dari proporsi ibu yang cukup banyak dalam beberapa pernyataan seperti ibu selalu menunjukkan rasa kasih sayang kepada anak $(88,3 \%)$, ibu membantu anak menyelesaikan masalahnya $(63,3 \%)$, ibu menyediakan waktu untuk berinteraksi dengan anak $(80,0 \%)$, ibu senang memeluk anak (83,3\%), ibu memuji anak ketika anak berprestasi $(80,0 \%)$, dan ibu sering bercanda dengan anak (76,7\%). Namun, penelitian ini juga menemukan bahwa masih terdapat 6,7 persen istri yang merasa interaksi ibu-anak berada pada kategori rendah.

\section{Kualitas Perkawinan}

Hasil penelitian menemukan bahwa proporsi terbesar istri kualitas perkawinannya pada kategori tinggi sekitar tiga dari empat istri. Berikut akan disajikan pembahasan untuk masing-masing dimensi kualitas perkawinan, yaitu kepuasan dan kebahagiaan perkawinan.

Kepuasan perkawinan. Berdasarkan hasil penelitian pada Tabel 3 dapat diketahui bahwa delapan dari sepuluh istri merasa puas dengan perkawinannya.Pada aspek cinta dan hubungan intim menunjukan bahwa lebih dari tiga perempat, istri merasa puas. Hal tersebut ditunjukkan dari pernyataan istri merasa suami memperlakukan seperti yang diinginkan $(86,7 \%)$, suami mencintainya $(95,0 \%)$, istri merasa puas dalam berhubungan intim $(96,7 \%)$, merasa puas terhadap yang dimiliki saat ini $(91,7 \%)$. Namun, beberapa istri masih ada yang merasa tidak puas dengan perkawinannya hal tersebut ditunjukkan pada pernyataan bahwa istri merasa tidak puas dalam hal keterbukaan membicarakan masalah seks $(23,3 \%)$, merasa hubungan intim tidak indah dan tidak intim lagi $(13,3 \%)$, merasa tidak puas dengan waktu luang yang diisi bersama pasangan (6,7\%).

Tabel 2 Sebaran istri berdasarkan kategori dimensi interaksi keluarga dan nilai minimum, maksimum, rata-rata, dan standar deviasi interaksi keluarga

\begin{tabular}{|c|c|c|c|c|c|c|c|c|}
\hline \multirow{3}{*}{ Dimensi Interaksi Keluarga } & \multicolumn{6}{|c|}{ Kategori } & \multirow{3}{*}{$\begin{array}{c}\text { Minimal- } \\
\text { Maksimal } \\
\text { (Indeks) }\end{array}$} & \multirow{3}{*}{$\begin{array}{l}\text { Rata-rata } \pm \\
\text { SD }\end{array}$} \\
\hline & \multicolumn{2}{|c|}{$\begin{array}{c}\text { Rendah } \\
(00,0-60,0)\end{array}$} & \multicolumn{2}{|c|}{$\begin{array}{c}\text { Sedang } \\
(60,0-79,0)\end{array}$} & \multicolumn{2}{|c|}{$\begin{array}{c}\text { Tinggi } \\
(80,0-100,0)\end{array}$} & & \\
\hline & $\mathrm{n}$ & $\%$ & $\mathrm{n}$ & $\%$ & $\mathrm{n}$ & $\%$ & & \\
\hline Interaksi suami-istri & 9 & 15,0 & 28 & 46,7 & 23 & 38,3 & $1-100$ & $72,93 \pm 19,75$ \\
\hline Interaksi ibu-anak & 4 & 6,7 & 16 & 26,7 & 40 & 66,7 & $1-99$ & $80,70 \pm 20,83$ \\
\hline Interaksi keluarga total & 4 & 6,7 & 24 & 40,0 & 32 & 53,3 & $1-99$ & $76,88 \pm 19,49$ \\
\hline
\end{tabular}


Sementara itu, pada aspek ekonomi lebih dari tiga perempat istri merasa puas dengan kondisi ekonomi keluarga hal ini ditunjukkan pada pernyataan istri merasa puas terhadap apa yang dimiliki saat ini $(91,7 \%)$, istri tidak mempermasalahkan pekerjaan pasangan $(93,3 \%)$, dan juga istri tidak merasa terganggu dengan campur tangan pasangan dalam mengatur keuangan (91,7\%). Namun, pada beberapa aspek ekonomi istri merasa tidak puas yaitu pada saat keluarga pasangan selalu minta bantuan keuangan $(11,7 \%)$, bertengkar karena tidak terbuka masalah keuangan $(13,3 \%)$, berbeda pendapat mengenai penggunaan keuangan keluarga $(23,3 \%)$, dan merasa terganggu dengan campur tangan orang lain dalam mencukupi keuangan keluarga $(8,3 \%)$. Selanjutnya, pada aspek pengasuhan anak masih ada beberapa istri yang merasa tidak puas karena sering konflik dalam pembagian tanggung jawab membesarkan anak-anak (15,0\%) dan bersitegang dalam menentukan pendidikan anak (13,3\%). Hal tersebut menunjukkan masih ada beberapa istri yang belum merasa puas dengan perkawinannya.

Kebahagiaan perkawinan. Dimensi kebahagiaan meliputi, aspek komitmen dengan pasangan, kepribadian pasangan, komunikasi dengan keluarga pasangan, ekonomi, dan pengasuhan anak. Berdasarkan hasil penelitian pada Tabel 3 menunjukkan bahwa tujuh dari sepuluh istri merasa puas (kepuasan terkategori tinggi) pada dimensi kebahagiaan perkawinan. Pada aspek komitmen perkawinan, istri merasa bahagia dalam hal pasangan menjaga komitmen perkawinan $(91,7 \%)$. Terdapat istri yang merasa pasangan berselingkuh (10,0\%). Secara umum juga ditemukan bahwa meskipun ada masalah dengan pasangan, istri tidak merasa terpaksa dalam melakukan hubungan intim dengan suami (83,3\%). Pada aspek komunikasi dengan keluarga pasangan, istri merasa bahagia karena istri tidak merasa terasing di tengah keluarga pasangan $(90,0 \%)$, istri mudah menganggap keluarga pasangan sebagai keluarga sendiri $(83,3 \%)$. Sementara itu, pada aspek kepribadian pasangan, lebih dari setengah istri merasa tidak bahagia dengan sifat pasangan $(71,7 \%)$ dan sikap pasangan $(63,3 \%)$. Temuan ini menarik karena mengindikasikan bahwa sifat dan sikap suami terhadap istri merupakan hal-hal yang membuat istri merasa tidak bahagia. Sementara itu, dalam hal pengasuhan anak, sebagian besar istri telah merasa bahagia. Hal tersebut ditunjukkan pada kehidupan suami istri yang jarang berkonflik dalam hal pengasuhan anak $(88,3 \%)$ dan mendidik anak $(86,7 \%)$. Namun, pada aspek ekonomi ada beberapa istri merasa selalu bersitegang dengan pasangan mengenai uang untuk makanan dan uang untuk pakaian $(11,7 \%)$. Hal ini menunjukkan masih adanya istri yang merasa kurang bahagia dalam perkawinannya karena seringnya bersitegang dengan suami terkait beberapa permasalahan pembagian keuangan untuk keperluan sehari-hari.

\section{Pengaruh Karakteristik Keluarga, Dukungan Sosial, dan Interaksi Keluarga terhadap Kualitas Perkawinan}

Hasil analisis regresi linier model variabelvariabel bebas dalam penelitian ini terhadap kualitas perkawinan seperti yang tersaji pada Tabel 4 menunjukkan angka Adjusted $R$ Square adalah 0,391 yang berarti model tersebut menjelaskan 31,9 persen variabelvariabel bebas di dalam model memengaruhi secara nyata kualitas perkawinan dan sisanya $(60,9 \%)$ dipengaruhi oleh variabel lain di luar penelitian ini. Hasil penelitian menunjukkan interaksi keluarga tersebut menjelaskan 39,1 $(\beta=0,519 ; p=0,000)$ berpengaruh positif secara nyata terhadap kualitas perkawinan. Setiap kenaikan kenaikan satu satuan interaksi keluarga maka akan menaikkan kualitas perkawinan sebesar 0,510 poin. Hal ini berarti interaksi keluarga yang semakin optimal maka akan mengoptimalkan kualitas perkawinan.

Tabel 3 Sebaran istri berdasarkan dimensi kualitas perkawinan dan nilai minimum, maksimum, rata-rata, dan standar deviasi kualitas perkawinan

\begin{tabular}{|c|c|c|c|c|c|c|c|c|}
\hline \multirow{3}{*}{$\begin{array}{c}\text { Dimensi Kualitas } \\
\text { Perkawinan }\end{array}$} & \multicolumn{6}{|c|}{ Kategori } & \multirow{3}{*}{$\begin{array}{l}\text { Minimal- } \\
\text { Maksimal } \\
\text { (Indeks) }\end{array}$} & \multirow{3}{*}{$\begin{array}{l}\text { Rata-rata } \pm \\
\text { SD }\end{array}$} \\
\hline & \multicolumn{2}{|c|}{$\begin{array}{c}\text { Rendah } \\
(00,0-60,0)\end{array}$} & \multicolumn{2}{|c|}{$\begin{array}{c}\text { Sedang } \\
(60,0-79,0)\end{array}$} & \multicolumn{2}{|c|}{$\begin{array}{c}\text { Tinggi } \\
(80,0-100,0)\end{array}$} & & \\
\hline & $\mathrm{n}$ & $\%$ & $\mathrm{n}$ & $\%$ & $\mathrm{n}$ & $\%$ & & \\
\hline $\begin{array}{l}\text { Kepuasan } \\
\text { Perkawinan }\end{array}$ & 4 & 6,7 & 8 & 13,3 & 48 & 80,0 & $15-100$ & $85,75 \pm 19,08$ \\
\hline $\begin{array}{l}\text { Kebahagiaan } \\
\text { Perkawinan }\end{array}$ & 7 & 11,7 & 9 & 15,0 & 44 & 73,3 & $10-100$ & $80,17 \pm 20,48$ \\
\hline $\begin{array}{l}\text { Kualitas } \\
\text { Perkawinan total }\end{array}$ & 6 & 10,0 & 8 & 13,3 & 46 & 76,7 & $13-100$ & $82,96 \pm 19,18$ \\
\hline
\end{tabular}


Tabel 4 Koefisen regresi linier bergada pengaruh karakteristik keluarga, dukungan sosial, dan interaksi keluarga terhadap kualitas perkawinan

\begin{tabular}{lccc}
\hline Variabel & $(\mathrm{B})$ & $(\beta)$ & Sig. \\
\hline Usia istri & 0,809 & 0,185 & 0,337 \\
$\begin{array}{l}\text { Lama } \\
\text { menikah }\end{array}$ & $-0,203$ & $-0,038$ & 0,796 \\
$\begin{array}{l}\text { Pendapatan } \\
\text { keluarga }\end{array}$ & $8,018 \mathrm{E}-7$ & 0,133 & 0,133 \\
$\begin{array}{l}\text { Besar } \\
\text { Keluarga }\end{array}$ & 1,370 & 0,049 & 0,660 \\
$\begin{array}{l}\text { Pendidikan } \\
\text { istri }\end{array}$ & $-2,337$ & $-0,104$ & 0,409 \\
$\begin{array}{l}\text { Pendidikan } \\
\text { suami }\end{array}$ & $-0,472$ & $-0,026$ & 0,835 \\
$\begin{array}{l}\text { Dukungan } \\
\text { sosial }\end{array}$ & 0,264 & 0,177 & 0,139 \\
$\begin{array}{l}\text { Interaksi } \\
\text { keluarga }\end{array}$ & 0,510 & 0,519 & \\
\hline Uji F & & & $0,000^{* *}$ \\
$\begin{array}{l}\text { Sig } \\
R \text { Square }\end{array}$ & & & 4,792 \\
Adjusted $R$ Square & & $0,000^{* *}$ \\
\hline $\begin{array}{l}\text { Keterangan: }{ }^{*} \text { Signifikan pada } \mathrm{p}<0,05 ;{ }^{* *} \text { Signifikan pada } \\
\text { p<0,01 }\end{array}$ & & \\
\end{tabular}

PEMBAHASAN

Peran ganda istri dijelaskan dalam konsep dualism cultural (Michelle \& Louise, 1974), yang terbagi dalam dua lingkungan, yaitu domestik dan publik. Peran domestik adalah peran yang dilakukan sebagai istri, ibu dan pengelola rumah tangga sedangkan peran publik merupakan peran yang ada di dalam lingkungan kerja, anggota masyarakat, dan organisasi. Dalam perspektif peran ganda ini, pada kasus istri bekerja, peran yang harus dijalankan istri secara bersamaan pada ranah domestik dan publik dapat menimbulkan ketegangan dan konflik peran (role strain) antara tuntutan pekerjaan dan keluarga. Kammeyer (1987) menyebutkan bahwa konflik peran dibagi ke dalam dua bentuk yaitu, a). beban berlebih, hal ini diartikan tuntutan dari dua sisi, yaitu pekerjaan dan rumah tangga melebihi kapasitas individu dalam mengatasi karena keterbatasan waktu dalam sehari untuk melakukan semua aktivitas. Konflik peran ganda yang kedua yaitu tumpang tindih (interference), dalam hal ini diartikan bahwa ada pekerjaan di kantor yang harus diselesaikan, sementara keluarga juga memiliki kewajiban yang harus dilaksanakan dalam waktu yang sama.

Konflik kerja-keluarga pada seseorang yang bekerja tentu saja merupakan kondisi yang tidak dapat dihindari. Konflik kerja-keluarga yang terjadi pada seseorang akan dapat mengganggu aktivitas di tempat kerja dan sekaligus menciptakan masalah pada situasi keluarga individu (Ghayyur \& Jamal, 2012). Hubungan negatif antara konflik kerja-keluarga dengan kepuasan perkawinan menunjukan bahwa wanita bekerja yang memiliki tingkat konflik kerja-keluarga yang rendah mengalami kepuasan yang lebih tinggi dalam peran pekerjaan maupun peran dalam keluarga (Judge et al., 2006). Hasil penelitian Puspitawati (2009) menemukan bahwa istri bekerja yang mementingkan pekerjaan daripada keluarga akan cenderung berkurang cara melakukan manajemen stres dan kesehatan mentalnya, sehingga memilih lebih banyak menghabiskan waktu untuk melakukan kegiatan personal, seperti tidur, guna melepaskan segala beban yang ditanggung, terutama beban pekerjaan. Selain itu, penelitian lain menemukan bahwa konflik kerja-keluarga berpengaruh negatif terhadap pelaksanaan tugas (dasar dan perkembangan) keluarga (Sunarti, Rizkillah, \& Muktiyah2014). Sementara itu, kepuasan perkawinan juga dapat dipengaruhi oleh pelaksanaan tugas keluarga seperti yang ditemukan bahwa keluarga yang mampu melaksanaan tugas perkembangan dengan baik berpengaruh nyata terhadap peningkatan kepuasan perkawinan keluarga (Tyas, Herawati, \& Sunarti, 2017; Rahmaita Krisnatuti, \& Yuliati, 2016).

Peningkatan partisipasi wanita bekerja mengindikasikan adanya potensi konflik kerjakeluarga yang berdampak terhadap kepuasan kerja pada keluarga dengan suami dan istri bekerja. Masalah di tempat kerja lebih mengganggu keluarga dibandingkan masalah keluarga menganggu pekerjaan. Keluarga dengan istri bekerja harus mengembangkan strategi penyeimbangan kerja dan keluarga.

Suami dan istri yang bekerja pada penelitian ini terkategori usia dewasa madya. Pada usia dewasa madya pasangan suami istri diharapkan dapat memiliki peran dan tugas untuk bekerja sama dalam melaksanakan tugas rumah tangga, dapat menjalin hubungan yang harmonis dalam keluarga, mengoptimalkan komunikasi efektif antaranggota keluarga, dan meningkatkan silaturahmi dengan keluarga besar. $\mathrm{Hal}$ tersebut tentu saja tidak terlepas dari upaya penyesuaian kebutuhan hidup dan pemenuhan tanggung jawab membesarkan anak oleh orang tua (Hastuti, 2015; Anderson \& Sabatelli, 2011). Hasil penelitian menunjukkan bahwa 
lama pendidikan istri lebih tinggi dari lama pendidikan suami. Abrar dan Ghouri (2010) menyebutkan bahwa pendidikan tinggi dapat mendorong istri untuk mencapai karir yang baik, sehingga menjadikan perempuan memiliki pendapatan yang dapat membantu kebutuhan ekonomi keluarga. Namun, berdasarkan hasil penelitian istri, dengan pendidikan lebih tinggi justru memiliki kualitas perkawinan yang cenderung rendah. Temuan ini mengindikasikan bahwa istri dalam penelitian ini yang memiliki tingkat pendidikan yang tinggi belum tentu dapat mengelola waktu dan permasalahan sehingga kualitas perkawinan belum tercapai secara optimal. Sementara itu, pendapatan per kapita keluarga terkategori tidak miskin. Menurut Simanjutak (2010), pendapatan yang tinggi menunjukkan kesejahteraan objektif pada keluarga dan hal tersebut mendorong peningkatan kepuasan dan kebahagiaan perkawinan dalam aspek ekonomi. Conger, Conger, dan Martin (2010) juga menambahkan bahwa kelas sosial atau status sosial ekonomi keluarga akan berkaitan dengan kepuasan dan stabilitas dalam perkawinan.

Hasil penelitian menunjukkan bahwa lebih dari setengah istri menerima dukungan sosial tinggi. Sunarti et al. (2005) menyebutkan bahwa dukungan sosial yang diterima keluarga dapat berupa dukungan fisik dan nonfisik berupa dukungan emosional, dukungan instrumental dan dukungan informasi. Hasil penelitian menunjukkan bahwa dukungan emosional yang optimal dari keluarga luas tercermin pada dukungan keluarga luas dalam mendengarkan masalah yang dihadapi istri, memperlihatkan perasan cinta dan kepedulian terhadap istri, hubungan yang akrab antara istri dan keluarga besar, dan istri merasa sebagai bagian penting dalam keluarga. Sementara itu, dukungan instrumental dan informasi yang diterima oleh istri sudah mencukupi namun masih ada beberapa hal dari aspek tersebut yang kurang optimal dalam hal memberikan bantuan keuangan dan pengasuhan anak.

Sunarti et al. (2005) menyebutkan bahwa dukungan sosial akan bernilai positif kepada keluarga jika dapat menjalankan fungsi dan perannya dengan optimal. Istri lebih banyak menerima dukungan dari keluarga, teman, dan pasangan, sementara suami cenderung mendapatkan dukungan sosial terbanyak hanya dari pasangan. Dukungan sosial emosional dan instrumental mampu melindungi keluarga dari tekanan ekonomi dan tekanan pekerjaan (Leinonen et al., 2003).
Hasil penelitian ini menunjukkan bahwa istri menerima dukungan sosial dari tetangga meliputi dukungan emosional, instrumental, dan informasi. Dukungan emosional yang diperoleh istri dari tetangga terlihat dari tingginya proporsi istri yang merasa dicintai dan merasa aman berada di lingkungan tersebut, dan istri merasa menjadi salah satu bagian di lingkungan masyarakat. Gunuc dan Dogan (2013) menyebutkan bahwa dukungan sosial tetangga mampu mendasari keluarga untuk melanjutkan hubungan sosial, mengatasi kesepian, beradapatasi, dan merasa aman berada di suatu lingkungan tertentu. Di sisi lain, penelitian ini menggambarkan bahwa tingginya dukungan sosial (keluarga luas dan tetangga) yang diberikan kepada istri menyebabkan tingginya interaksi keluarga dan memberikan dampak positif pada istri untuk mempertahankan kedekatan hubungan melalui interaksi yang baik. Menurut Puspitawati (2009), dukungan yang diberikan keluarga besar berupa kepedulian dan perhatian yang tinggi mampu memberikan dorongan untuk tetap semangat dan dukungan verbal yang diberikan oleh keluarga dapat menjaga interaksi yang baik dalam keluarga. Permasalahan yang muncul pada suami istri bekerja, seperti stres dapat diatasi dengan memberikan dukungan sosial pada pasangan suami istri bekerja. Dukungan sosial dapat memengaruhi interaksi individu di dalam keluarga yaitu dukungan emosional terhadap pasangan (Selvarajan et al., 2013). Persepsi dukungan sosial berpengaruh terhadap kepuasan pernikahan (Nawaz et al., 2014).

Hasil penelitian ini menemukan bahwa proporsi terbesar interaksi suami-istri berada pada kategori sedang. Menurut Waldinger dan Schulz (2006), interaksi suami istri adalah hubungan yang terjalin antarpasangan yang melibatkan perasaan dan kontrol emosi dan tingginya interaksi suami-istri menyebabkan semakin tingginya kualitas perkawinan. Penelitian ini juga menemukan masih adanya interaksi suami-istri yang berada pada kategori rendah. Meskipun begitu, penelitian ini menemukan bahwa proporsi terbesar interaksi ibu-anak terkategori tinggi, meskipun ada beberapa yang berada pada kategori.

Sunarti (2013) menyatakan bahwa suami-istri yang jarang melakukan interaksi berdampak buruk terhadap hubungan perkawinan. Interaksi yang kurang baik bisa mendatangkan penyakit, ketidakbahagiaan perkawinan, bahkan membawa ke perceraian. Menurut Puspitawati dan Setioningsih (2011), interaksi suami-istri yang rendah akan menimbulkan 
masalah untuk pasangan dan akan berdampak pada kualitas perkawinan. Hasil penelitian Leaderman et al. (2010) ditemukan bahwa interaksi keluarga yang rendah dapat memengaruhi stres keluarga dan berdampak pada kualitas perkawinan. Nezhad et al. (2010) menyebutkan bahwa pada ibu bekerja, beberapa permasalahan yang memengaruhi interaksi keluarga diantaranya yaitu kurangnya waktu bersama anak, stres, dan mengalami kesulitan dalam mengerjakan pekerjaan sehari-hari di rumah. Untuk mengatasi permasalahan tersebut ibu dapat melakukan penyeimbangan dan pembagian peran dengan keluarga serta meminta dukungan dari keluarga luas.

Selanjutnya, penelitian ini menduga bahwa interaksi keluarga merupakan salah satu faktor penentu kualitas perkawinan Penelitian lain telah menemukan bahwa tingginya interaksi suami-istri menyebabkan semakin tingginya kualitas perkawinan (Allendorf \& Ghimire, 2013). Kualitas perkawinan tercermin dari hubungan yang dekat dan harmonis serta adanya prinsip yang dipegang dalam bentuk kebahagiaan dan kepuasan perkawinan (Sunarti et al., 2005). Berdasarkan hasil penelitian ini ditemukan bahwa proposi terbesar istri merasa kualitas perkawinan tinggi. Berdasarkan hasil penelitian memperlihatkan bahwa sebagian besar istri merasa puas dengan perkawinan saat ini. Pada aspek cinta dan hubungan intim hasil penelitian menunjukan bahwa lebih dari tiga perempat, istri merasa puas. Menurut Lavner et al. (2014), kepuasan perkawinan dilandasi oleh rasa cinta pada pasangan dengan menunjukkan ekspresi cinta dari waktu ke waktu. Hasil penelitian menunjukkan bahwa pada aspek ekonomi lebih dari tiga perempat istri merasa puas dengan kondisi ekonomi keluarga. Hal ini ditunjukkan dari proporsi terbesar istri yang merasa puas terhadap apa yang dimiliki saat ini, istri tidak mempermasalahkan pekerjaan pasangan, dan istri merasa puas apabila mengatur keuangan bersama dengan suami. Namun, pada beberapa aspek ekonomi, istri merasa tidak puas yaitu pada saat keluarga pasangan selalu minta bantuan keuangan dan berbeda pendapat mengenai penggunaan keuangan keluarga. Menurut Tyas dan Herawati (2017), permasalahan keluarga dalam aspek ekonomi akan meningkatkan konflik sehingga permasalahan tersebut harus diatasi oleh pasangan.

Selain kepuasan, kualitas perkawinan dalam penelitian ini juga dibangun dari dimensi kebahagiaan. Kebahagiaan bersifat subjektif dan berkaitan dengan kenikmatan yang dialami seseorang terhadap objek yang bisa dicapainya, seperti aspek kepribadian, ekonomi, dan sosial (Sunarti et al., 2005). Hasil penelitian menemukan bahwa lebih dari setengah istri menyatakan kebahagiaan perkawinannya dalam kategori tinggi. Pada dimensi kebahagiaan, proporsi terbesar istri ditemukan pada aspek komitmen perkawinan. Temuan menunjukkan bahwa lebih dari tiga perempat istri selalu menjaga komitmen perkawinan. Hal ini sesuai dengan penelitian Sunarti et al. (2005) yang menemukan bahwa kebahagiaan tercapai dengan adanya komitmen bersama dan saling mendukung. Hal ini sejalan dengan penelitian Tyas \& Herawati (2017) yang juga menemukan bahwa kebahagiaan perkawinan dapat tercapai dengan adanya komunikasi dan keterbukaan antara pasangan dan keluarga pasangan.

Menurut Sunarti et al. (2005) aspek sosial berpengaruh terhadap kualitas perkawinan. Perkawinan yang diterima oleh keluarga besar dan lingkungan di sekitar akan mendapat dukungan yang baik dari keluarga dan tetangga. Kersh et al. (2006) juga menyatakan bahwa salah satu faktor yang memengaruhi kualitas pernikahan dari pasangan suami dan istri adalah dukungan sosial. Menurut Yadzani et al. (2016) dan Eskisu (2014), dalam kehidupan perkawinan dukungan sosial sangat dibutuhkan untuk memberikan rasa tenang, percaya diri dan merasa diperhatikan sehingga dapat meningkatkan kemampuan mengatasi berbagai permasalahan dalam keluarga yang akan berdampak pada meningkatnya kualitas perkawinan.

Berdasarkan hasil penelitian menunjukkan bahwa interaksi keluarga memiliki pengaruh terhadap kualitas perkawinan. Interaksi keluarga dapat dioptimalkan dengan keterbukaan komunikasi antaranggota keluarga, menjalin hubungan antara orang tua, anak, dan keluarga besar dengan baik sehingga kualitas perkawinan dapat tercapai secara maksimal. Hal ini sesuai dengan penelitian Allendorf dan Ghimire (2013) yang menemukan bahwa interaksi keluarga merupakan salah satu faktor penentu kualitas perkawinan. Penelitian Sunarti et al. (2005) yang menemukan bahwa kualitas perkawinan diperoleh dari keharmonisan komunikasi keluarga sehingga tercapai suasana nyaman untuk mengoptimalkan pengasuhan yang diberikan kepada anak, tingginya interaksi keluarga menyebabkan tingginya kualitas perkawinan. Menurut Waldinger dan Schulz 
(2006), salah satu masalah yang muncul ketika istri memiliki peran ganda adalah menurunnya intensitas interaksi keluarga, namun hal tersebut dapat diatasi dengan kerja sama anggota keluarga untuk menjalankan tugas dan melibatkan dukungan emosional positif dalam keluarga. Keterbatasan penelitian ini adalah lokasi penelitian hanya dilakukan di beberapa institusi di Kota Bogor, sehingga tidak dapat menggambarkan seluruh Kota Bogor dan responden yang mengisi kuisioner hanya istri sehingga penelitian ini hanya mengukur semua variabel berdasarkan perceived (yang dirasakan) istri/ibu saja.

\section{SIMPULAN DAN SARAN}

Usia istri dan usia suami pada penelitian ini berada pada usia madya dan besar keluarga berada pada kategori keluarga kecil. Pendidikan istri lebih tinggi (16 tahun) daripada pendidikan suami (15 tahun). Istri bekerja sebagai PNS, namun jenis pekerjaan suami cukup beragam. Rata-rata pendapatan per kapita keluarga per bulan sebesar Rp2.569.643,00 dan seluruh keluarga dalam penelitian ini bukan terkategori keluarga miskin. Dukungan sosial yang dirasakan sebagian besar istri terkategori tinggi. Dukungan sosial tinggi diperoleh istri dari keluarga besar dan tetangga, capaian tertinggi dukungan sosial yaitu pada aspek dukungan emosional dan capaian terendah pada aspek dukungan instrumental. Keadaan ini menggambarkan adanya interaksi yang positif dan hubungan saling mendukung antara istri, keluarga inti, keluarga besar dan lingkungan sekitar yang menghasilkan kepuasan bagi anggotanya. Tingkat interaksi suami-istri berada pada kategori sedang dan interaksi ibuanak berada pada kategori tinggi. Kualitas perkawinan pada dimensi kepuasan memiliki capaian yang tinggi pada aspek cinta dan hubungan intim dan terendah pada aspek pengasuhan anak. Dimensi kebahagiaan menunjukkan capaian tertinggi pada aspek komitmen perkawinan dan terendah pada aspek kepribadian pasangan. Berdasarkan uji regresi kualitas perkawinan dipengaruhi positif signifikan oleh interaksi keluarga.

Berdasarkan hasil penelitian interaksi keluarga memengaruhi kualitas perkawinan, sehingga diharapkan keluarga suami-istri bekerja sebaiknya lebih meningkatkan alokasi waktu bersama keluarga secara optimal danInteraksi keluarga pada keluarga suami-istri bekerja dapat dioptimalkan dengan memahami pengaturan waktu dan pembagian peran melalui penyuluhan dari LSM atau Perguruan
Tinggi. Penelitian selanjutnya diharapkan melibatkan suami dalam wawancara dan melakukan kajian yang berhubungan dengan keluarga suami dan istri bekerja seperti stres, tekanan ekonomi, kesejahteraan keluarga, dan sebagainya.

\section{DAFTAR PUSTAKA}

Abrar, N., \& Ghouri, A.M. (2010). Dual earners and balance in their family and work life: findings from Pakistan. European Journal of Social Science, 17(1): 28-40

Allendorf, K., Ghimire, D. J. (2013). Determinants of marital quality in an arranged marriage society. Social Science Research, 42 (1): 59-70, DOI: 10.1016/j.ssresearch.2012.09.002

Anderson, \& Sabatelli. (2011). Family Interaction. USA: Pearson Education.Inc.

Bulanda, J.R., Brown, J.S., Yamashita, T. (2016). Marital quality, marital dissolution, and mortality risk during the later life course. Social Science \& Medicine, 165 (2016): 119127,DOI:10.1016/j.socscimed.2016.07.0 25

Carr, D., Freedman, V. A., Cornman, J. C., \& Schwarz, N. (2014). Happy marriage, happy life? Marital quality and subjective well-being in later life. Journal of Marriage and Family. 76: 930-948.DOI: 10.1111/jomf.12133

Chuang, Y. C. (2005). Effecs of interaction pattern on family harmony and well being: test of interpersonal theory, relational model theory, and Confucian ethics. Asian Journal Of Social Psychology. 8(3): 272-291. DOI: https://doi.org/10.1111/j.1467839X.2005.00174.x

Conger, R. D., Conger, K. J., \& Martin, M. J. (2010). Socioeconomic status, family processes, and indivisual development. Journal of Marriage and Family, 72, 685704, doi: 10.1111/j.17413737.2010.00725.x

Eskisu, M. (2014). The Relationship between bullying, family functions and perceived social Support Among High School Students. Social and Behavioral Sciences, 159 ( 2014 ) 492 - 496, DOI: https://doi.org/10.1016/j.sbspro.2014.12. 412 
Greenhaus, J. H., \& Beutell, N. J. (1985). Sources of Conflict between Work and Family Roles. Academy of Management Review, 10: 76-88.

Gunuc, S., \& Dogan, A. (2013). The relationship between turkish adolescents internet addiction, their perceived social support and family activities. Computer in Human Behavior, 29 (2013); 2197-2207, DOI: https://doi.org/10.1016/j.chb.2013.04.01 1

Hastuti, D. (2015). Pengasuhan: teori dan prisip serta aplikasinya di Indonesia. Bogor, ID: IPB Press.

Judge, T. A., Ilies, R., \& Scott, B. A. (2006). Work-family conflict and emotions: effects at work and at home. Personnel Psychology, 59: 779-814, DOI: https://doi.org/10.1111/j.17446570.2006.00054.x

Kammeyer, K. C. W. (1987). Marriage and Family: a Foundation for Personal Decision. Massachusetts: Allyn \& Bacon

Kerkmann, B. C., Lee, T. R., Lown, J. M., \& Allgood, S. M. (2000). Financial management, financial problems, and marital satisfaction among recently married university students. Financial Counseling and Planning, 11 (2), 55-65

Kersh, J., Hedvat, T. T., Hauser-Cram, P., \& Warfleld, M. E. (2006). The contribution of marital quality to the well-being of parents of children with developmental disabilities. Journal of Intellectual Disability Research, 50(12), 883-893, DOI: 10.1111/j.1365-2788.2006.00906.x

Khan, F., Aftab, S. (2013). Marital satisfaction and perceived social support as vulnerability factors to depression. American International Journal of Social Science. 2 (5): 99-107.

Kusumowardhani, R. P. A. (2012). Gambaran kepuasan perkawinan pada istri bekerja. Proyeksi 6(1): 1-15.

Larasati, A. (2012). Kepuasan perkawinan pada istri ditinjau dari keterlibatan suami dalam menghadapi tuntutan ekonomi dan pembagian peran dalam rumah tangga. Jur. Psikologi Pendidikan dan Perkembangan 1(3) : 1-5.

Lavner, J. A., Karney, B. R., \& Bradbury, T. N. (2014). Relationship problems over the early years of marriage: stability or change?. Journal of Family Psychology, 28(6), 979-985. DOI: 10.1037/a0037752.

Ledermann, T., Bodenmann, G., Rudaz, M., Bradbury, T. (2010). Stress, Communication, and Marital Quality in Couples. Journal of Family Relations, 59: 195- 206, DOI: https://doi.org/10.1111/j.1741-

3729.2010.00595.x

Leinonen, J. A., Solantaus, T. S.j,, \& Punamaki, R. L. (2003). Social support and the quality of parenting under economic pressure and workload in Finland: the role of family structure and parental gender. J Fam Psychol. 17 (3): 409-418, DOI: 10.1037/08933200.17.3.409

Lewis RA, Spanier GB. 1979. Theorizing about the quality and stability of marriage. Dalam WR Burr, R. Hill., F. I. Nye.,\& IL Reiss (Eds.). Contemporary theories about the family Vol 2. New York (US): The Free Press.

Litcher., \& Carmalt. (2008). Religion and marital quality among low income couples. Social Science Research, 38 (1): 168-187, DOI: https://doi.org/10.1016/j.ssresearch.2008 .07 .003 .

Nawaz, S., Javeed, S., Haneef, A., Tasaur, B., \& Khalid, I. (2014). Perceived social support and marital satisfaction among love and arranged marriage couples. International Journal of Academic Research and Reflection, 2 (2): 41-50.

Nezhad, M. Z., Goodarzi, A. M., Hasannejad, L., \& Roushani, K. (2010). Occupational stress and family difficulties of working women. Current Research in Psychology, 1(2) : 75-81.

Pratiwi, H. (2016). Hubungan antara Dukungan Sosial Keluarga dengan Kepuasan Perkawinan pada Istri. Jurnal IImiah Mahasiswa Universitas Surabaya, 5(1): 1-11.

Puspitawati, H. (2009). Pengaruh strategi penyeimbangan antara aktivitas pekerjaan dan keluarga terhadap kesejahteraan keluarga subjektif pada perempuan bekerja di Bogor: Analisis structural equation modelling. Jur. IIm. Kel. \& Kons, 2(2), 111-121, DOI: http://dx.doi.org/10.24156/jikk.2009.2.2.1 11 
Puspitawati, H. (2012). Gender dan Keluarga: Konsep dan Realita di Indonesia. Bogor (ID): IPB Press.

Puspitawati, H., \& Setioningsih, S. S. (2011). Fungsi Pengasuhan dan Interaksi dalam Keluarga Terhadap Kualitas Perkawinan dan Kondisi Anak pada Keluarga Tenaga Kerja Wanita (TKW). Jurnal Ilmu Keluarga dan Konsumen, 4(1):11-20,DOI: http://dx.doi.org/10.24156/jikk.2011.4.1.1 1

Rahmaita, Krisnatuti D., \& Yuliati L. N. (2016). Pengaruh tugas perkembangan keluarga terhadap kepuasan perkawinan ibu yang baru memiliki anak pertama. Jurnal IImu Keluarga dan Konsumen, 9(1), 1-10, DOI:

http://dx.doi.org/10.24156/jikk.2016.9.1.1

Rizkillah. (2014). Kualitas Perkawinan dan Lingkungan Pengasuhan pada Keluarga dengan Suami Istri Bekerja (Tesis). Institut Pertanian Bogor, Bogor, Indonesia

Selvarajan, T. T., Cloninger, P.A., Singh, B. (2013). Social support and work-family conflict: A test of an indirect effects model. Journal of Vocational Behavior, 83:486-499,

DOI: https://doi.org/10.1016/j.jvb.2013.07.004

Simanjuntak, M. (2010). Faktor-Faktor yang Meemengaruhi Kesejahteraan Keluarga dan Prestasi Belajar Anak pada Keluarga Penerima Program Keluarga Harapan (PKH) (Tesis). Institut Pertanian Bogor, Bogor, Indonesia

Sunarti E. (2013). Ketahanan keluarga. Bogor (ID): IPB Press.

Sunarti, E., Hakim, F. A,, Zakiya, N., \& Damayanti, R. (2014). The Effect ofWork-Family Conlictand Family Resource Managementto Accomplishment of Family Task. Paper will be presented at Work Family Researchers Network Conference. June 18-21, 2014 in New York

Sunarti, E., Rizkillah, R., Muktiyah, N. T. (2014). The Effect of Work-Family
Conflict and Balancing Strategy towards Wives Job Satisfaction in Dual Earner Family. Paper presented at International Work and Family research network: New York.

Sunarti, E., Tati., Nuraini, A. S., Noorhaisma, R., \& Lembayung, D. P. (2005). Pengaruh tekanan ekonomi, dukungan sosial, kualitas pernikahan, pengasuhan, dan kecerdasaran emosi anak terhadap prestasi belajar anak. Media Gizi \& Keluarga 29 (1) : 34-40.

Susmayanti, T., Sumarwan U., Kusno, S. R. (1995) Faktor-faktor yang memengaruhi kebahagiaan perkawinan pada ibu bekerja dan tidak bekerja. Media Gizi dan Keluarga. 19 (1): 18-27

Tyas, F. P. S., Herawati, T. (2017). Kualitas pernikahan dan kesejahteraan keluarga menentukan kualitas lingkungan pengasuhan anak pada pasangan yang menikah usia muda. Jurnal IImu Keluarga dan Konsumen, 10 (1): 112,DOI: http://dx.doi.org/10.24156/jikk.2017.10.1. 1

Tyas, F. P. S., Herawati, T., Sunarti, E. (2017). Tugas perkembangan keluarga dan kepuasan pernikahan pada pasangan menikah usia muda. Jurnal IImu Keluarga dan Konsumen, 10(2):8394.DOI: http://dx.doi.org/10.24156/jikk.2017.10.2. 83

Waldinger \& Schulz. (2006). Linking hearts and minds in couple interactions: intentions, attributions, and overriding sentiments. Journal of Family Psychology, 20(3): 494-504, DOI: 10.1037/0893-3200.20.3.494

Wheatley, D. (2014). Travel to work and subjective well being: Astudy of UK dual career households. Journal of Transport Geography. 39: 187-196, DOI: https://doi.org/10.1016/j.jtrangeo.2014.0 7.009 